\title{
WAR LOANS, INFLATION AND THE HIGH COST OF LIVING
}

\author{
By Carl SNyder,
}

Author of American Railways As Investments, New York City.

The relation of government loans to inflation seems more a question of fact than of theory. At least in a broad way there seems no inherent reason why such loans should cause inflation, or even expansion. A very large part of the loans is paid for by checkprobably 75 per cent or more, so that the actual flotation means little more than a transfer of bank credits. There is no withdrawal from or addition to the currency of the country; therefore on the modern theory, no effect upon prices. And I am taking it that the question of inflation is purely a question of prices-that if there has been no rise in prices there has been no inflation.

\section{Ways in which Loans Cause InfLation}

But as a matter of fact such loans do cause credit expansion; and therefore the question is, how? Certain ways are obvious.

First. There is always a great deal of hoarded gold, in small sums and large. And there is nothing like a great national crisis and an offer of government bonds to attract this gold from its hiding places in safety deposit vaults and old stockings and the like. So, for example, Germany without importations from abroad, has since the war began nearly doubled its visible gold holdings. As you know it has even encouraged the melting of plate and jewelry of all sorts. This gold has been exchanged for bank notes, but the effect would not have been very different if the gold had been exchanged for government bonds and then been placed where it was most needed -in the banks-to build up credits.

Second. A government loan, unless the proceeds are sent abroad, means government spending on a huge scale; and there is nothing like this spending to speed up business and therefore prices. If it now happens that this falls at a time when the banks are not loaned up to the limit and have room for credit expansion, this expansion is pretty sure to take place. That was actually the case 
last April when we entered the war. The banks were up to less than 90 per cent of what might be regarded as a normal safe maximum of loans; and they could therefore expand credits by at least a billion and a half, and conceivably a great deal more. If they could exchange for gold the billion or more of governmental securities which our banks have loaded up with since the war began, then even the normal expansion might readily be five or six billions; and as we shall see in a moment it could now be vastly more.

Third. Credit expansion naturally follows from the creation of a huge amount of good new bank collateral. Thousands of people will, in war time, buy bonds with the feeling that they can be realized on at any moment; and that moment usually comes for such people rather soon.

Fourth. A way has been, as it were, created by the new income tax law, assessing the unused surpluses of corporations at 10 per cent per annum. If these surpluses are converted into government bonds this tax can be avoided; and the bonds can then be used as collateral to 80 or 90 per cent of their face value and, under pledge of the banks, at the same rate of interest the bonds themselves bring. These loans reappearing as deposits, we should have then two deposits where the:e was only one before, and the credit currency has been expanded by a corresponding amount.

Fifth. In England and Germany, and probably more or less in all countries, the war has occasioned heavy government borrowings from the banks, these borrowings being repaid from time to time by the flotation of enormous loans. This borrowing, of course, being paid out to contractors and others, promptly appears as deposits and the volume of credit has therefore been expanded by about the amount so borrowed. This, in the judgment of The Economist of London, has been the principal form of credit expansion in England and chiefly responsible for a rise in prices of 135 per cent to date. So far this method has not been resorted to in the United States.

Sixth. There still remains the highly important matter of financing the loans themselves directly by means of bank credits to the buyers. This has been the chief means of flotation of the two loans so far put out in this country. I have asked several banking officials to estimate the extent to which it has been employed and they seem roughly to agree that on the first liberty loan for two 
billions, the banks may have loaned somewhere near half the total, and on the second loan even more. No such expansion was evident in the national bank statements between June and September; but the answer of the bankers is that first, a large part of these loans was repaid with surprising rapidity, and second, that in this period there was a considerable curtailment of general business credits. The next bank statement will give us a better idea of the facts; for it is probable that the advances on the second loan would not be repaid so quickly, if for no other reason than that they may have been two or three times as large as on the first.

We see, then, that as a practical matter government loans may cause a heavy expansion of bank credits, and even, as in the case of Germany, a very considerable addition to the metallic basis of these credits. The question remains: When and how does such an expansion become inflation?

\section{Money and Prices}

Here is the old, old problem of the relation between money and prices. There may be modes of inflation which do not spell high or rising prices; but they are of academic interest only. In the same way there may be other ways in which prices may be inflated than by the simple one of currency inflation, but I do not think I shall go beyond the bounds to say that these have no practical interest. As to the main issue, we are coming finally to a general agreement.

For example, our general stock of money now is between four and five billions. I do not suppose there is an economist living who would suggest that the government could flood the country with an issue of say ten billions of paper money without an enormous rise in prices. This is what Russia has done and the general increase in prices there, a reliable index being lacking, has been estimated at from 250 to 400 per cent. The whole controversy has always been rather a question of degree. I am of those who believe that the whole problem was cleared up and put upon an inexpugnable basis more than thirty years ago by our own Simon Newcomb and Professor Shield Nicholson in Britain, and later by the statistical investigations of Professor Kemmerer and the splendid work of Professor Irving Fisher. The whole theory, as you know, is expressed with the simple formula that prices vary directly as the volume of the actual currency employed, and its rate of turnover or velocity, and inversely with the volume of trade. 
Now as everyone knows, our main currency is in checks drawn against bank deposits. More than 90 per cent of the colossal exchanges of the nation, soaring now toward perhaps a thousand billions a year, are effected by means of checks. The volume of actual money in circulation is of slight consequence. Bank deposits in their turn are largely created by bank loans- 80 per cent and more. The total of these loans is always many times the total stock of actual money. So, on the present-day theory, the level of prices represents a ratio between bank credits and the current volume of business.

I have found this simple fact very puzzling to many people. But it becomes very clear when we imagine the banks restored to their old note-issuing power and giving out newly printed bank notes when they make a loan instead of merely entering a credit in their books. Anyone can see that an excessive issue of such notes would mean currency inflation; and an excessive expansion of deposits has the same effect. It follows, therefore, that if bank credits are expanded more rapidly than the actual volume of business we have a rise in prices, that is to say, inflation. This is the whole matter in a nutshell.

Now what is the actual situation in regard to business in this country? The railroads cannot haul any more goods. The government is already stepping in to shut down on shipments on certain lines of industry. We cannot get any more coal unless labor is drafted from other industries. And as a whole we cannot get any more labor, as is evident from the fantastic wages that are now being paid. In a word, production, and therefore the actual volume of exchanges is practically at the limit and has been for a year or more. No expansion of bank credits can put this production any higher. It follows, therefore, as a practical fact that any expansion of bank loans now means inflation - to all practical intents, dollar for dollar.

\section{EfFects of Credit Expansion}

Every scheme which increases bank credits spells increased cost of living and the discontent and social unrest that go with it, to say nothing of the genuine distress of millions of people whose incomes and salaries are more or less fixed and incapable of quick adjustment. With expanding credits, all the executive edicts and price fixings and food administrations in the world cannot keep prices down. 
You might just as well think to restrain them with a bunch of feathers after you have put under them a 30,000-ton hydraulic jack.

Now if all this be true, in encouraging tremendous credits on the purchase of government bonds, the administration and our bankers have to that extent deliberately set out on a policy of higher and higher prices. The slogan "Borrow and Buy" means in its effect exactly the same as if the government had printed a corresponding amount of fiat money and turned it loose, as in the days of our Civil War.

The war has already added to the stock of this country a billion of new gold, which has resulted in a credit expansion of nearly 50 per cent and a rise in general prices of nearly 100 per cent. This means that the war will cost us, as it is costing England and other nations, roughly twice what it would have cost if there had been no such inflation. If we go on expanding banking credits at the same rapid rate, the cost of living and of the war will be doubled again.

And after all this inflation comes the inevitable deflation which always follows wildcat finance, just as it did in the years following the Civil War, with the result of making the burden of debt at least twice as great as it otherwise would have been if inflation had not been resorted to. One-half of the cost of the war in Europe has come within the last year and in turn the second year's cost was almost double that of the first. If we spend fifteen or twenty billions this year, it may readily mean thirty or forty billions next year, and if the war lasts three years more, as many believe it will, our burden of debt may readily reach a total of fifty or sixty billions, or more. The practical question then is whether this shall be met by "genuine saving," as the editor of The Economist terms it, or by some form of inflation, as has been true of all the nations of Europe?

\section{Possible Inflation under the Reserve System}

I do not know how many among you have considered how far the inflation of our actual currency may go. The volume of checkable deposits is now around fourteen billions. Will it stagger you to know that a prominent New York banker estimated that bank loan expansion, if the war lasts, might readily reach fifty billions? And all of this is provided for under our new Federal Reserve System. It is strange how few people realize the perfectly fantastic possibilities of credit expansion which were created by the new 
amendments to the Federal Reserve Act passed last June. Under these amendments the required reserves were cut more than half over those formerly enforced under the national banking system and instead of these reserves being in gold or lawful money, they are now to be nothing more than book credits with the Federal Reserve Banks. And in turn these banks have only to hold a 35 per cent gold reserve against these credits.

It follows, therefore, that every dollar of gold may become $\$ 3$ of federal bank credits, and each dollar of this may in turn become the basis of $\$ 8$ of credits for the central reserve cities, $\$ 10$ for the smaller cities and $\$ 15$ for the country banks, which works out to a practical average of $\$ 10$ for all the banks of the Federal Reserve System.

The Federal Reserve Banks have now on hand a billion and a half of gold. If the present movement to bring in all the eligible state banks, trust companies and the like is successful, this gold reserve may readily reach between two and three billions, and therefore serve as a basis for fifty or sixty billions, or more, of bank credits.

You will see, therefore, that the new reserve system has created possibilities of inflation never dreamt of since the Civil War. And all that stands between the general public and this inflation and the dizzy level of prices which it would bring in its train is the good sense and conservatism of our bankers, with such encouragement as they may receive from a political board at Washington and their political appointees, the governors of the Federal Reserve Banks.

So far this source of inflation has remained practically untouched. ${ }^{1}$ Would it be possible to leave it untouched, no matter what the exigencies of the war? Is it the counsel of perfection to suggest that any great war can be fought without inflation? I know there are many able and conservative economists, as for example, Mr. George E. Roberts, who are inclined to doubt if it could. On the other hand, Mr. Hartley Withers, the editor of The Economist of London, has preached this very counsel from the

${ }^{1}$ Note of December 5. Since this article was written, this bank credit inflation seems under way on a gigantic scale.. In a few weeks the loans of the New York banks alone have increased more than half a billion, an expansion without parallel in the history of the Clearing House. Coincidently Dun's Index of Commodity Prices reaches the highest point in its history. Yet there seems not a single journal of influence in America, not a member of Congress, or senator who understands the problem or offers a word of protest or warning. 
beginning of the war; and has unweariedly attacked the ineptitude of the British government and its makeshift finance. If such a policy would be possible to England with an ante-war income of not much over ten billions of our money, assuredly it would be possible for the United States with an ante-war income of at least three or four times this.

\section{A Problem of Expediency}

The problem as I see it is the everlasting one of expediency. Obviously inflation is "the easiest way." As the slang phrase goes, it is "easy money." Our bankers feel highly patriotic when they turn in for a tremendous campaign for bond subscriptions; and Mr. McAdoo and the administration at Washington feel highly elated when they roll up five billions of subscriptions, half of which are merely bank loans. It seems to matter little that all this may add two or three billions to the already swollen credit currency, and that the millions of poor people, small investors and life insurance holders who cannot expand their incomes in any adequate way must pay the piper. These are the millions who rarely have any voice in national affairs, and all the more so because they are for the most part un-understanding and dumb. To them matters of finance and economics are a seven-sealed book, and there seems to be no one save the most ignorant and demagogic of politicians to give heed to their wrongs.

But the alternative to inflation would be a sharp curtailment of our reckless national extravagance; it would mean drastic saving and the almost total discontinuance, for example, of the manufacture of a million five hundred thousand new automobiles a year. It would mean a contraction rather than an expansion of credits. It would mean tight money and high interest rates. And all this is practically what no business man or borrower or any political administration ever wants. Everybody wants easy money, flush times and three rousing cheers for the success of a loan campaign, no matter how it is achieved.

It seems an idle consequence that we may spend perhaps ten long weary years of "hard times," of falling prices, declining business and sharp distress, paying for the orgy of infiated prices, waste and extravagance in which we are now indulging. 